\title{
Nutrient distribution and structure affect the acidification of eutrophic ocean margins: A case study in southwestern coast of the Laizhou Bay, China
}

\author{
Jinfeng Zhang ${ }^{\mathrm{a}, \mathrm{b}}$, Xuelu Gao ${ }^{\mathrm{a}, *}$ \\ a Key Laboratory of Coastal Environmental Processes and Ecological Remediation, Yantai Institute of Coastal Zone Research, Chinese Academy of Sciences, Yantai, Shandong 264003, China \\ b College of Chemistry and Materials Science, Ludong University, Yantai, Shandong 264001, China
}

\section{A R T I C L E I N F O}

\section{Article history:}

Received 24 March 2015

Received in revised form 22 June 2016

Accepted 27 June 2016

Available online 8 July 2016

\section{Keywords:}

Nutrients

Ocean acidification

Coastal waters

Eutrophication

\begin{abstract}
A B S T R A C T
The effects of nutrient distribution and structure on the acidity of coastal waters were analyzed based on the data of 48 surface water samples collected in the southwestern coast of the Laizhou Bay and its adjacent rivers (SWLZB) which are heavily influenced by nutrient-laden discharges. The concentration and structure of nutrients varied considerably along the coast owing to different contributors. The studied inshore waters exhibited a sign of acidification. The $\mathrm{pH}$ was significantly negatively correlated with the concentration of $\mathrm{NO}_{3}-\mathrm{N}, \mathrm{NO}_{2}-\mathrm{N}, \mathrm{NH}_{4}-\mathrm{N}$ and DSi, but showed no obvious correlation with the concentration of $\mathrm{PO}_{4}-\mathrm{P}$ and the ratio of TDN/TDP, DSi/DIN and DSi/PO $4-\mathrm{P}$, respectively. The results indicated that the distribution of nutrients might well be an important environmental factor affecting the acidification of the SWLZB in warmer months.
\end{abstract}

(c) 2016 Elsevier Ltd. All rights reserved.

\section{Introduction}

It is well-known that nutrient over-enrichment is a major environmental problem in many coastal areas around the world (Cloern, 2001; Seitzinger et al., 2005; Song, 2011). Coastal areas are regions with high population density and intense human activities, accounting for $\sim 30 \%$ of the total net oceanic primary production (Alongi, 1998; Gattuso et al., 1998; Dürr et al., 2011; Song, 2011). Large amounts of nutrients have been transported from land to coastal areas by rivers in the past decades due to the rapid increase of human activities, resulting in environmental deterioration and biogeochemical process variation (Seitzinger et al., 2005; Halpern et al., 2008; Qu and Kroeze, 2010). The concentration and composition of nutrients could not only affect the biomass and composition of phytoplankton but also cause largescale algal bloom when there is too much of them (Gao and Song, 2005; Song, 2011; Smetacek and Zingone, 2013; Xing et al., 2015). Benefiting from the nutrient enrichment, many microbial species are flourishing in eutrophic coastal seas, and their respiration could release much $\mathrm{CO}_{2}$ which may lower the seawater $\mathrm{pH}$ in these areas (Cai et al., 2011; Wallace et al., 2014). In addition, some nutrients may exist in the form of acid or weak base, for instance, $\mathrm{N}$ may exist as $\mathrm{HNO}_{3}$ or $\mathrm{NH}_{3}$ in some particular situations, which may affect the acidity of seawaters directly. Ocean acidification (OA) induced by human activities, especially in coastal regions, has aroused great concern in recent years

\footnotetext{
* Corresponding author.

E-mail address: xlgao@yic.ac.cn (X. Gao).
}

(Caldeira and Wickett, 2003; Canadell et al., 2007; Quéré et al., 2013). From the preindustrial period to the 1990s, the mean $\mathrm{pH}$ of global surface oceans had decreased from approximately 8.2 to 8.1, corresponding to a $26 \%$ increase in the acidity of the oceans as measured by the concentration of hydrogen ion (Gattuso and Hansson, 2011). With few exceptions, this change exceeded that in any period in the last 300 million years, and is projected to continue to influence the world oceans of greater depths progressively (Caldeira and Wickett, 2003). The majorities of marine bios reside in the surface ocean and are exposed to this progressive increase of seawater acidity. Microbes collectively support marine food webs, and the activities of biota influence the composition of dissolved chemicals and particulate organic materials and moderate the exchange of nutrient elements such as carbon, nitrogen, phosphorous between the ocean waters (Cooley et al., 2009), and all these processes are subject to OA. Although OA and nutrients in coastal waters have intimate interactions, at present there is little research concerning the effects of nutrient distribution and structure on $\mathrm{OA}$.

The effects of nutrient distribution and structure on OA may be evidenced in waters of the southwestern coast of the Laizhou Bay (SWLZB). There are ten rivers (Yihonghe River, Guanglihe River, Zhimaihe River, Xiaoqinghe River, Mihe River, Yuhe River, Bailanghe River, Dihe River, Weihe River, and Jiaolaihe River) flowing into the Laizhou Bay from its southwestern coast, most of which are small and seasonal. Due to abundant seawater resources and underground brine resources, a chemical industrial base called the Weifang Binhai Economic Development Zone is located along its southwestern coast. Over 400 chemical enterprises are located nearby and $>150$ kinds of chemical products are 
manufactured in this area. Thus, large quantities of $\mathrm{CO}_{2}, \mathrm{SO}_{2}$ and $\mathrm{NO}_{2}$ were produced in these chemical industrial activities (Qin, 2010), which may affect the acidity of the coastal waters of the SWLZB. In addition, the river waters carry large amounts of nutrients derived from many point sources such as industrial effluents and agricultural runoff, non-purified or insufficiently purified wastewaters discharged into the inshore waters of this area (SOA, 2009; SOA, 2012). Therefore, the aquatic environment of the SWLZB is in a eutrophic state (Zhang et al., 2015). Different rivers have different nutrient concentration and composition which may change the concentration and structure of nutrients in the inshore waters along the coast. Such a condition in the SWLZB provided the opportunities for the analysis of the interactions between nutrients and OA.

This study tried to determine the concentrations of total dissolved nitrogen (TDN), dissolved inorganic nitrogen (DIN), nitrate nitrogen $\left(\mathrm{NO}_{3}-\mathrm{N}\right)$, nitrite nitrogen $\left(\mathrm{NO}_{2}-\mathrm{N}\right)$, ammonium nitrogen $\left(\mathrm{NH}_{4}-\mathrm{N}\right)$, dissolved organic nitrogen (DON), total dissolved phosphorus (TDP), reactive phosphorus (orthophosphate-P; $\mathrm{PO}_{4}-\mathrm{P}$ ), dissolved organic phosphorus (DOP), and dissolved silicate (DSi) in the surface waters of the SWLZB and the pH in the same sites with a purpose of attempting to analyze the interactions between the distribution or structure of nutrients and $\mathrm{OA}$.

\section{Materials and methods}

\subsection{Sample collection}

The research was carried out during 23 September to 1 October 2012, which is after the peak period of the rainy season. The sampling stations were arranged in the flowing direction of the major rivers in this area covering about $15-20 \mathrm{~km}$ from the high tide mark to the land and about $10 \mathrm{~km}$ from the high tide mark to the sea, and keeping about 2-3 km from each other (Fig. 1). The river stations arranged in ten rivers of the SWLZB coast, which are Yihonghe River (YHH), Guanglihe River (GLH), Zhimaihe River (ZMH), Xiaoqinghe River (XQH), Mihe River $(\mathrm{MH})$, Yuhe River (YH), Bailanghe River (BLH), Dihe River (DH), Weihe River (WH), and Jiaolaihe River (JLH). The sampling sites in the inshore waters formed five transects, here named as L-transect (sites L1, L2, L3, L4 and L5), K-transect (sites K1, K2 and K3), J-transect ( sites J1, J2, J3 and J4), I-transect (sites I1, I2 and I3) and H-transect ( sites $\mathrm{H} 1, \mathrm{H} 2$ and $\mathrm{H} 3$ ). A total of 48 water samples were collected from the surface (depth of $\sim 0.5 \mathrm{~m}$ ) using well cleaned polyethylene bottles (pre-conditioned for $24 \mathrm{~h}$ in 1:10 nitrate acid solution and rinsed well with $18.2 \mathrm{M} \Omega$-cm deionized water). The samples were stored in a cooler box with ice bags, and then refrigerated at $4{ }^{\circ} \mathrm{C}$ within $12 \mathrm{~h}$ until further analysis. All the samples were filtered with cellulose acetate membrane filters (Whatman ${ }^{\circledR}, 0.45 \mu \mathrm{m}$ ) before nutrient determination.

\subsection{Analytical methods}

TDN, $\mathrm{NO}_{3}-\mathrm{N}, \mathrm{NO}_{2}-\mathrm{N}, \mathrm{NH}_{4}-\mathrm{N}, \mathrm{TDP}, \mathrm{PO}_{4}-\mathrm{P}$ and DSi were measured using continuous flow analyzer (SEAL AutoAnalyzer 3, German). The analytical precision for TDN, $\mathrm{NO}_{3}-\mathrm{N}, \mathrm{NO}_{2}-\mathrm{N}, \mathrm{NH}_{4}-\mathrm{N}, \mathrm{TDP}, \mathrm{PO}_{4}-\mathrm{P}$ and DSi was assessed by multiple analysis of standards and replicates. The precision of the analyses of standard solution was better than $5 \%$, which was consistent with the previous report of Liu et al. (2011); all analyses of the samples were carried out in duplicate and the relative standard deviations were $<10 \%$, and the results were expressed as the means. The concentrations of dissolved inorganic nitrogen (DIN) were the sum of $\mathrm{NO}_{3}-\mathrm{N}, \mathrm{NO}_{2}-\mathrm{N}$ and $\mathrm{NH}_{4}-\mathrm{N}$. The concentrations of dissolved organic nitrogen (DON) and phosphorus (DOP) were estimated by the subtractions of DIN from TDN and $\mathrm{PO}_{4}$-P from TDP, respectively.

The $\mathrm{pH}$ values were determined in situ using a portable Orion Star-A combined instrument equipped with an Orion ${ }^{\circledR}$ 8107UWMMD Ross combination electrode (Thermo Scientific, Singapore) for the precision of $\mathrm{pH}$ analysis. The $\mathrm{pH}$ buffers adopted were three NIST (National Institute of Standards and Technology, the US Department of Commerce)traceable pH buffers. According to the results of Zhai et al. (2012), in the Bohai Sea, the $\mathrm{pH}$ values on the total-hydrogen-ion scale $\left(\mathrm{pH}_{\mathrm{T}}\right)$ were lower than the NIST-traceable $\mathrm{pH}$ values by $0.143 \pm 0.006 \mathrm{pH}$ units (mean \pm standard deviation, $n=73$ ). Based on this result, we transferred the NIST-traceable $\mathrm{pH}$ data to the total-hydrogen-ion scale $\left(\mathrm{pH}_{\mathrm{T}}\right)$.

\subsection{Statistical analysis}

All data were tested for normality with the Shapiro-Wilk test before analysis. The Spearman correlation-coefficient was used to analyze the relationship between $\mathrm{pH}_{\mathrm{T}}$ and nutrient concentrations or ratios. In this research, a value of $P<0.05$ was considered to indicate a significant difference in all statistical analysis. Multiple regression analysis was used to estimate the coefficients of the linear equation, based on which the value of the dependent variable could be well predicted. The analyses were performed through the Origin statistical package version 7.0.

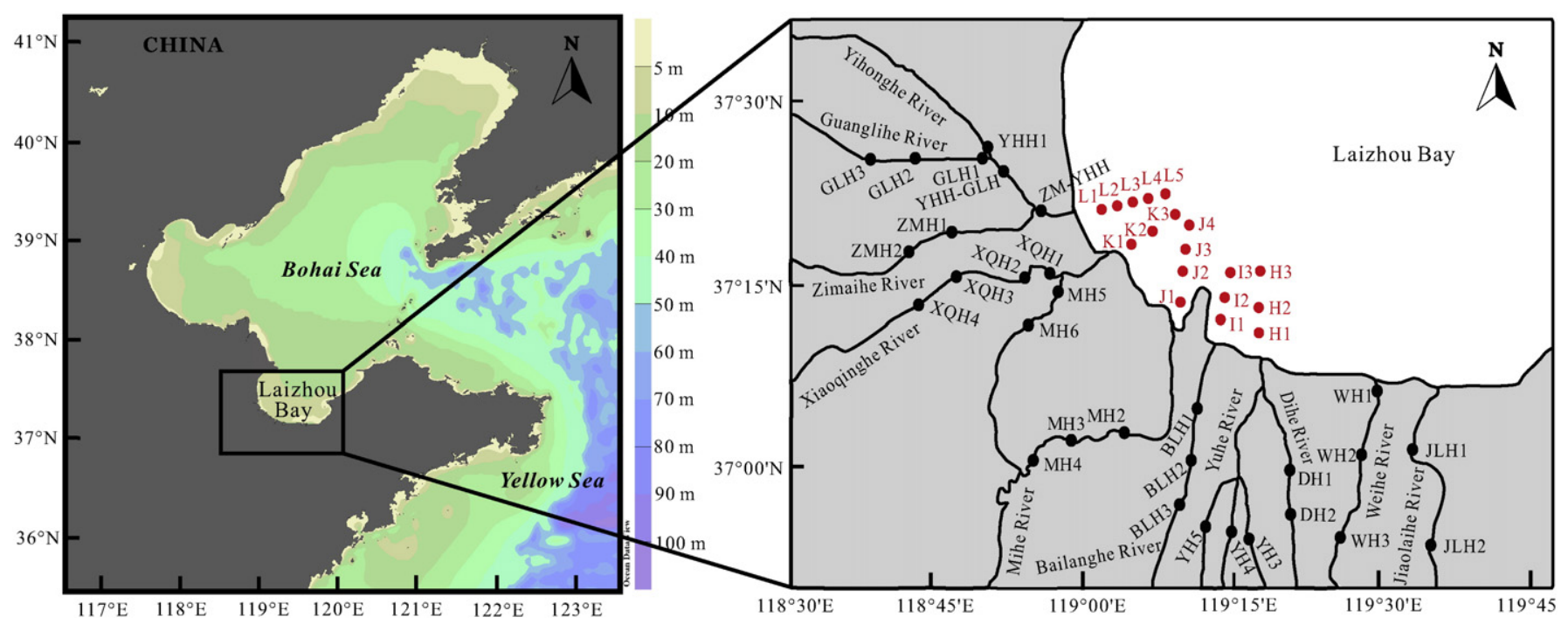

Fig. 1. Location of sampling stations in the coastal waters of the SWLZB. The marine sampling stations were shown in red dots and the riverine ones were shown in black. 


\section{Results and discussion}

\subsection{The acidity $(\mathrm{pH})$ in the studied region}

The $\mathrm{pH}$ values on total-hydrogen-ion scale $\left(\mathrm{pH}_{\mathrm{T}}\right)$ in the studied areas varied from 7.16 to 8.64 with an average of 7.81 (Fig. 2). It could be seen in Fig. 2 that the $\mathrm{pH}_{\mathrm{T}}$ values in $81.5 \%$ of the total sampling sites were below the average $\mathrm{pH}_{\mathrm{T}}$ values of the world oceans (varied from 7.9 to 8.3 with an average of 8.1 on the total-hydrogen-ion scale) (Ryuichi et al., 2013). The $\mathrm{pH}_{\mathrm{T}}$ values in the inshore waters varied from 7.56 to 8.26 with an average of 7.93 (Fig. 2), which increased in the seaward direction (Fig. 2). It could be seen in Fig. 2 that the $\mathrm{pH}_{\mathrm{T}}$ values in $88.9 \%$ of the marine sites were below the average $\mathrm{pH}_{\mathrm{T}}$ values of the world oceans (8.1) (Ryuichi et al., 2013). Moreover, the decadal changes of $\mathrm{pH}_{\mathrm{T}}$ values in the Laizhou Bay surface waters demonstrated a decreasing trend, although these data were obtained in different areas and months in the Laizhou Bay, from 8.11 in 1987 to 7.93 in 2012 (Fig. 3), indicating a sign of gradual acidification (Figs. 2 and 3). The different inshore transects exhibited different degrees of acidification: the $\mathrm{pH}_{\mathrm{T}}$ values of L-transect, K-transect, J-transect, I-transect and H-transect were in the range of 7.69-8.00, 7.91-8.06, 7.84-8.03, 7.56-8.18 and 7.96-8.26, with a mean value of $7.87,7.98,7.96,7.78$ and 8.10 , respectively, and all of the five marine transects were acidified to some extent compared with those reported values that were shown in Fig. 3. Among them, the I-transect was the most seriously acidified one, followed by L-transect, J-transect, K-transect and H-transect.

\subsection{Distribution characteristics of nutrient species}

Spatial distributions of nutrient species including TDN, DIN $\left(\mathrm{NO}_{3}-\mathrm{N}\right.$, $\mathrm{NO}_{2}-\mathrm{N}$ and $\mathrm{NH}_{4}-\mathrm{N}$ ), DON, TDP, $\mathrm{PO}_{4}-\mathrm{P}, \mathrm{DOP}$ and DSi in the inshore transects are shown in Fig. 4. Although the distribution of different nutrient species in the whole inshore area showed different patterns, a common distribution characteristic was identified that the order of their corresponding concentrations was K-transect $>\mathrm{H}$-transect $>\mathrm{L}$ transect $>$ J-transect $>$ I-transect for most of the studied inorganic nutrient species. Such a pattern was generally corresponding to the nutrient concentrations in the adjacent rivers (Fig. 4), indicating that the concentrations of nutrients in the SWLZB could be intimately associated with river inputs. In order to demonstrate the relationship between nutrient behavior and river inputs in the studied areas, the average concentrations of nutrient species in the SWLZB adjacent rivers were calculated and shown in Fig. 4. It could be seen that TDN concentrations in the western rivers were generally higher than those in the eastern rivers (except for the $\mathrm{YH}$ ), and the DIN concentrations were lower than DON concentrations except for the XQH. The highest DIN concentration was found in the $\mathrm{XQH}$ (Fig. 4a). In the L-transect adjacent rivers (LTAR), the concentrations of $\mathrm{NH}_{4}-\mathrm{N}$ were higher than those of $\mathrm{NO}_{3}-\mathrm{N}$ and $\mathrm{NO}_{2}-\mathrm{N}$; while in other four rivers, $\mathrm{NO}_{3}-\mathrm{N}$ was the species with highest

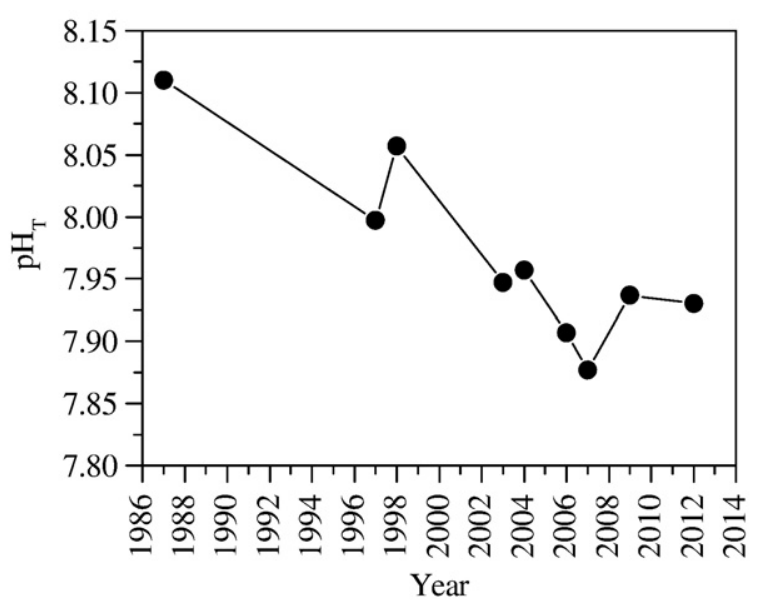

Fig. 3. Decadal change of average $\mathrm{pH}_{\mathrm{T}}$ in the Laizhou Bay. The $\mathrm{pH}_{\mathrm{NIST}}$ values from literature were converted to $\mathrm{pH}_{\mathrm{T}}$ according to the $\mathrm{pH}_{\mathrm{NIST}}$ and $\mathrm{pH}_{\mathrm{T}}$ relationship in Zhai et al. (2012). Data sources: 1987: Jiang et al., 1991; 1997: Mi et al., 2001; 1998: Cheng, 2004; 2003: SOA, 2004; 2004: SOA, 2005; 2006: Ying et al., 2014; 2009: SOA, 2010; 2012: present study.

concentration (Fig. 4b). Specially, the YH has the highest TDN and DON concentration, and DON concentrations were much higher than DIN concentrations in this river (Fig. 4b), such a special situation probably associated with the fact that the Yuhe River flows through the Weifang Binhai Economic Development Zone which has been suffering from point source pollution of industrial wastes. The higher DON and TDP concentrations in the LAR may be due to the crude oil exploitation activities in the basin of the Yihonghe River, Guanglihe River and Zhimaihe River, which flow through the second largest oilfield (Shengli Oilfield) of China. The higher nutrient concentration in the XQH may be explained by the fact that the Xiaoqinghe River, the largest river in the studied areas, which is originated from Jinan City, flows through eight counties of Shangdong Province, with extensive reconstruction for flood control, sailing, irrigation and sewage discharge (Ma et al., 2004), and is heavily influenced by human activities. It was also found that TDP concentrations in the western rivers were generally higher than those in the eastern ones (Fig. 4c), especially for $\mathrm{PO}_{4}-\mathrm{P}$ (Fig. 4c). The highest TDP and $\mathrm{PO}_{4}-\mathrm{P}$ concentrations were found in the $\mathrm{ZMH}$, which was probably associated with the fact that the Zhimaihe River flows through the rural areas of Guangrao City-an agriculture dominant region where large amounts of phosphate fertilizer are used (Dongying Statistical Yearbook, 2013). In fact, the agriculture of the western part of the studied areas has been generally more developed than that of the eastern part (Dongying Statistical Yearbook, 2013), suggesting that nutrients in this part may be more associated with agricultural activities. Therefore, the transportation and behavior of nutrients in the SWLZB

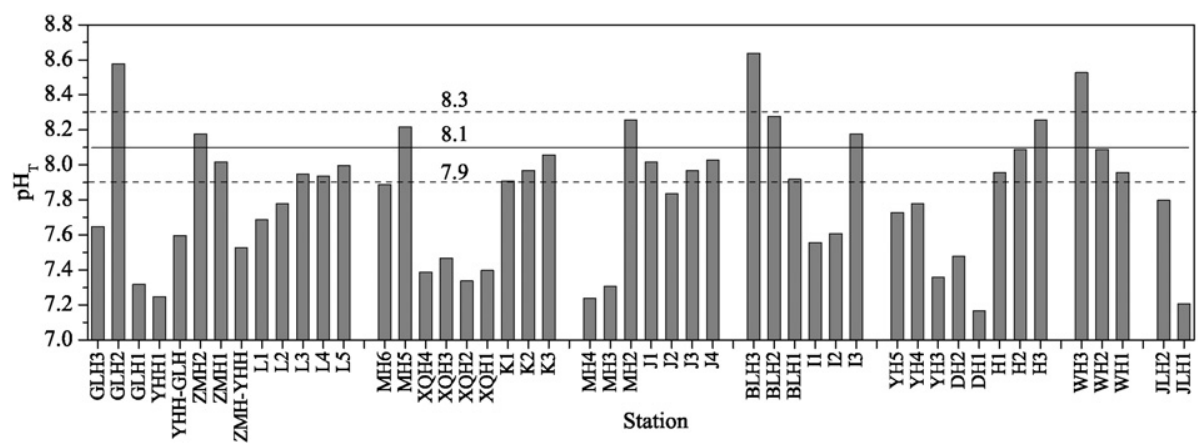

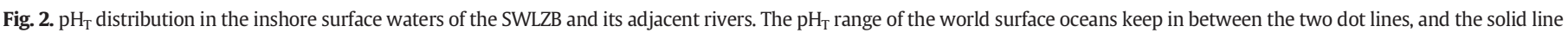
indicates the present average $\mathrm{pH}_{\mathrm{T}}$ of the world surface ocean. 

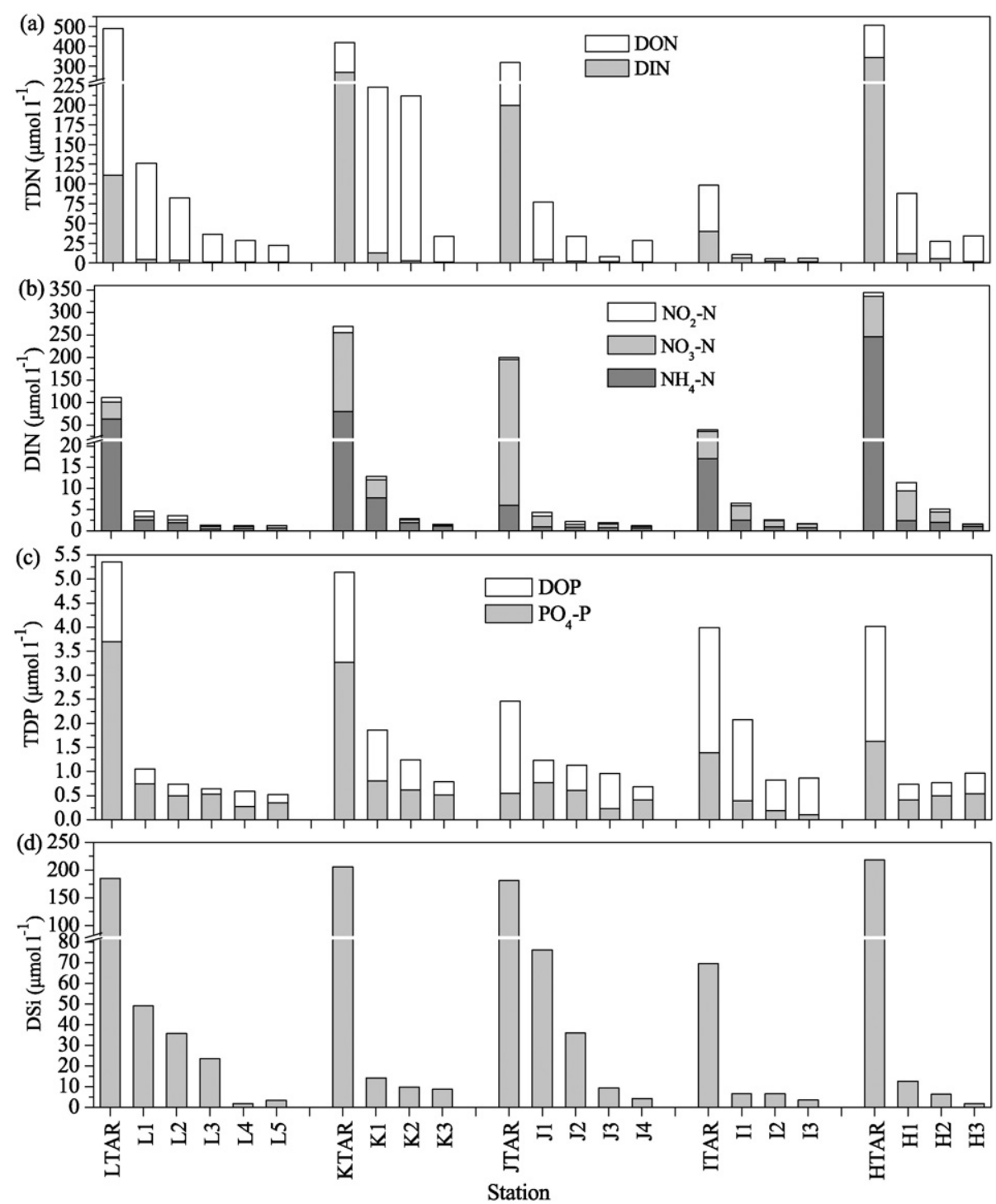

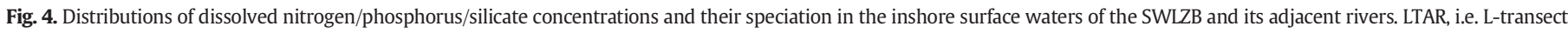

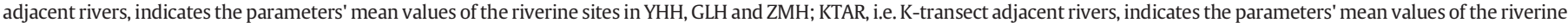

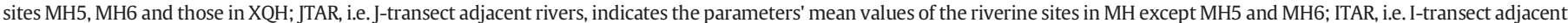

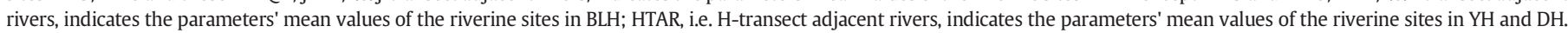

adjacent rivers were influenced by crude oil exploitation activities, industrial and agricultural activities, similar to that of the Baltic Sea (Kiedrzyńska et al., 2014).

\subsubsection{Dissolved nitrogen}

The concentrations of dissolved nitrogen constituents in the SWLZB varied greatly along the coast (Fig. 4a). The concentrations of TDN, DIN, $\mathrm{NO}_{3}-\mathrm{N}, \mathrm{NO}_{2}-\mathrm{N}, \mathrm{NH}_{4}-\mathrm{N}$ and DON in the surface waters of the SWLZB were in the range of 5.29-506.5, 1.17-344.3, 0.31-189.2, 0.05-14.05, 0.43245.9 and $2.63-378.5 \mu \mathrm{mol} 1^{-1}$, with an average of $126.7,44.9,23.5$, $2.18,19.2$ and $81.8 \mu \mathrm{mol} \mathrm{l}^{-1}$, respectively. In the studied inshore waters, the concentrations of dissolved nitrogen constituents also varied greatly along the coast (Fig. 4a), which decreased significantly in the seaward direction; K-transect had the highest TDN concentrations, followed by H-transect, L-transect, J-transect and I-transect; L-transect and K-transect were generally enriched with DON relative to DIN, while the reverse was true for the rest of the studied transects. All the sampling transects had the marine sampling sites with DIN concentrations exceeding the upper limit of seawater standard Grade IV of China for this parameter $\left(2.5 \mu \mathrm{mol} \mathrm{l}^{-1}\right)$. The highest average DIN concentration $5.75 \mu \mathrm{mol} \mathrm{l^{-1 }}$ was found in K-transect; the lowest value $2.41 \mu \mathrm{mol} \mathrm{l}^{-1}$, which still exceeded the upper limit of seawater standard Grade I of China for this parameter $\left(1.5 \mu \mathrm{mol} \mathrm{l}^{-1}\right)$, was found in J-transect. So it could be concluded that the SWLZB was enriched with nitrogen.

K-transect had the highest nitrogen concentrations which indicated that nitrogen in this transect was heavily influenced by human activities, because the Xiaoqinghe River is a relatively big one among the rivers discharging into the SWLZB with extensive anthropogenic disturbance as aforementioned (Ma et al., 2004; SOA, 2009; SOA, 2012). This can be illustrated by Fig. 4 in which it could be seen that $\mathrm{XQH}$ had the highest nitrogen concentrations among the studied rivers.

The general DIN structure characteristics in L-transect and K-transect were $\mathrm{NH}_{4}-\mathrm{N}>\mathrm{NO}_{3}-\mathrm{N}>\mathrm{NO}_{2}-\mathrm{N}$ (except at L1, L2, L5); in J-transect, I-transect and $\mathrm{H}$-transect, the characteristics were $\mathrm{NO}_{3}-\mathrm{N}>\mathrm{NH}_{4}-$ $\mathrm{N}>\mathrm{NO}_{2}-\mathrm{N}$ (except at J2, J4, H3) (Fig. 4b); specially, in K-transect, DIN was dominated by $\mathrm{NH}_{4}-\mathrm{N}$, which accounted for $>50 \%$ of DIN in all the sampling sites (Fig. 4b). These patterns in the studied marine transects 
were generally similar to those in their corresponding rivers (Fig. 4b), further indicating that the river inputs could be the dominant source of nitrogen in the studied inshore waters. The concentrations of $\mathrm{NO}_{2}-\mathrm{N}$ were higher than $\mathrm{NO}_{3}-\mathrm{N}$ at $\mathrm{L} 1$ and $\mathrm{L} 2$ which may be due to the point pollution of industrial wastes from Dongying City. K-transect had the highest $\mathrm{NH}_{4}-\mathrm{N}$ concentrations (mean $3.61 \mu \mathrm{mol} \mathrm{l}{ }^{-1}$ ), which further illustrated the complexity of nitrogen sources in K-transect. The average concentrations of $\mathrm{NO}_{2}-\mathrm{N}$ in the five marine sampling transects remained at the same level, indicating that $\mathrm{NO}_{2}-\mathrm{N}$ in the studied inshore waters, on the whole, was very likely to be from non-point sources.

\subsubsection{Dissolved phosphorus}

The concentrations of TDP, $\mathrm{PO}_{4}-\mathrm{P}$ and DOP in the surface waters of the SWLZB were in the range of $0.22-6,30,0.10-3.70$ and 0.12 $2.60 \mu \mathrm{mol} \mathrm{l}^{-1}$, with an average of $1.68,0.83$ and $0.85 \mu \mathrm{mol} \mathrm{l}^{-1}$, respectively (Fig. 4c). The concentrations of dissolved phosphorus decreased in the seaward direction except in H-transect. Except I-transect, all the other transects had a few sampling sites with $\mathrm{PO}_{4}-\mathrm{P}$ concentrations exceeding the seawater standard Grade I of China for reactive phosphorus $\left(0.5 \mu \mathrm{mol} \mathrm{l}{ }^{-1}\right)$. Although the relatively higher TDN concentration was found in I-transect (I1), the average $\mathrm{PO}_{4}-\mathrm{P}$ concentration in I-transect was the lowest among the five transects $\left(0.23 \mu \mathrm{mol} \mathrm{l}^{-1}\right)$. Only in K-transect the average $\mathrm{PO}_{4}-\mathrm{P}$ concentration exceeded the seawater standard Grade I of China for reactive phosphorus $\left(0.5 \mu \mathrm{mol} \mathrm{l}^{-1}\right)$ among the sampling transects. L-transect, K-transect, J-transect and $\mathrm{H}$-transect were generally enriched with $\mathrm{PO}_{4}-\mathrm{P}$ relative to $\mathrm{DOP}$, while the I-transect were generally enriched with DOP relative to $\mathrm{PO}_{4}-\mathrm{P}$ (Fig. 4c). Like dissolved nitrogen, these patterns in the studied marine transects were generally similar to those in their corresponding rivers (Fig. 4c), indicating phosphorus in the SWLZB could be originated mainly from river inputs too. As above mentioned, phosphorus in the studied area associated with agricultural activities, which suggested that land use pattern could influence the distribution and speciation of dissolved phosphorus in the SWLZB.

The average concentration of reactive phosphorus in the five sampling transects was relatively low, and such results were similar to the results of the survey conducted in the inshore waters in the Yellow River Estuary by Liu et al. (2012), indicating nutrients in the inshore areas of the Laizhou Bay had high nitrogen concentration and low phosphorus concentration. The K-transect had the highest $\mathrm{PO}_{4}-\mathrm{P}$ concentration which further indicated that nutrients in that area were heavily influenced by human activities.

\subsubsection{Dissolved silicate}

The concentrations of DSi in the surface waters of the SWLZB were in the range of 1.82-218.3 $\mu \mathrm{mol} 1^{-1}$ with an average of $50.8 \mu \mathrm{mol} \mathrm{l}^{-1}$ (Fig. $4 \mathrm{~d})$. The dissolved silicate in the inshore waters of the SWLZB varied greatly along the coast, and decreased significantly in the seaward direction. J-transect had the highest DSi concentrations, followed by Ltransect, K-transect, H-transect and I-transect (Fig. 4d). The distribution pattern of DSi in the inshore waters was generally similar with that in the corresponding adjacent rivers (see Fig. 4d) indicating DSi in the SWLZB was also influenced by river inputs. The DSi concentrations in most inshore sites remained a mean value of $5.7 \mu \mathrm{mol} 1^{-1}$, but its values in some inshore sites from L-transect (L1, L2 and L3) and from J-transect (J1 and J2) were relatively high (mean $44.1 \mu \mathrm{mol}^{-1}$ ). The DSi distribution exhibited similar patterns with TDP in the studied rivers (see Fig. 4d). In certain instances silicate minerals originated from crust and their behaviors are less influenced by human activities. However, the crude oil exploitation activities and the sea salt production activities in the bank of the SWLZB could release more silicate minerals from crust into the water system, because of such activities digging more clay and rock (the major ingredients of them are silicate minerals) from underground to the surface.

\subsection{Structure of nutrients in the SWLZB}

The molar ratios of TDN/TDP, DIN/PO 4 -P, DSi/DIN and DSi/PO $4-\mathrm{P}$ in the whole studied areas were in the range of 5.1-248.8, 2.5-497.6, 0.5-17.7 and 3.4-932.9 with an average value of 95.4, 86.6, 3.1 and 106.9 , respectively.

Nutrient stoichiometry in seawaters is widely used in assessing the nutrient limitation of phytoplankton growth in marine ecosystems. Therefore, nutrient ratios in the inshore waters were specially analyzed in this study. The TDN/TDP ratios of L-transect, K-transect, J-transect, Itransect and H-transect were in the range of 41.7-122.4, 43.8-171.5, 23.2-62.6, 31.7-40.6 and 35.6-168.6 (Fig. 5a) with a mean value of $76.7,111.6,39.5,37.1$ and 92.3 , respectively. Its spatial variation was very distinct, indicating that different rivers input nutrients of different structures. The J-transect and I-transect had relatively lower TDN/TDP ratios related to higher TDP concentrations. Generally, the studied region had very high TDN concentrations and low TDP concentrations.

The DIN/ $/ \mathrm{PO}_{4}$-P ratios of the 18 marine sampling stations in the inshore waters ranged from 25.0 to 285.7 (Fig. 5b). Its spatial variation was also distinct. The DIN/PO 4 -P ratios of L-transect, K-transect, J-transect, I-transect and H-transect were in the range of 25.0-72.1, 30.6$160.9,29.3-82.3,132.9-177.1$ and 31.2-285.7 (Fig. 5b) with a mean value of 47.8, 79.6, 51.3, 157.7 and 139.8 , respectively. The $\mathrm{DIN} / \mathrm{PO}_{4}-\mathrm{P}$ ratios for all the sampling stations were higher than $22: 1$, which means a P limitation condition according to the research of Justic et al. (1995). The highest ratio (285.7) was found in H-transect (Fig. 5b). Except for I-transect, the spatial distribution of $\mathrm{DIN} / \mathrm{PO}_{4}-\mathrm{P}$ ratio for the other transects were similar to that of the TDN/TDP ratio.

DSi/DIN ratios in the inshore waters mainly ranged from 0.1 to 0.5 in $\mathrm{K}$-transect, I-transect and $\mathrm{H}$-transect, and a relatively wide range of 0.5 to 1.7 was found in L-transect and J-transect (Fig. 5c). The DSi/DIN ratios of about $60 \%$ of the marine sampling sites were $<0.5$ and the low ratios were mainly found in I-transect and $\mathrm{H}$-transect. The DSi/DIN ratios of Ltransect, K-transect, J-transect, I-transect and $\mathrm{H}$-transect were in the range of $0.2-1.1,0.1-0.6,0.4-1.7,0.1-0.3$ and $0.1-0.2$ (Fig. $5 \mathrm{c}$ ) with a mean value of $0.9,0.3,1.1,0.2$ and 0.1 , respectively.

Ratios of $\mathrm{DSi} / \mathrm{PO}_{4}-\mathrm{P}$ in the inshore waters ranged from 3.5 to 99.5 with three of the five sampling transects being higher than 22:1 (Fig. $5 \mathrm{~d})$. The high ratios were mainly found in L-transect and J-transect. Different from the wide variation of TDN/TDP and DIN/PO $-\mathrm{P}$ in K-transect, there were no significant variations of $\mathrm{DSi} / \mathrm{PO}_{4}-\mathrm{P}$ in $\mathrm{K}$-transect. The $\mathrm{DSi} /$ $\mathrm{PO}_{4}$-P ratios of L-transect, K-transect, J-transect, I-transect and H-transect were in the range of 7.2-66.9, 16.4-17.8, 10.8-99.3, 16.3-36.1 and 3.5-31.9 (Fig. 5d) with a mean value of 39.8, 17.3, 52.6, 28.3, and 16.0 , respectively.

Based on the spatial distribution patterns of DIN, $\mathrm{PO}_{4}-\mathrm{P}$ and DSi, it could be concluded that the spatial distribution patterns of DIN/PO $/ \mathrm{P}_{4}-\mathrm{P}$, $\mathrm{DSi} / \mathrm{DIN}$ and $\mathrm{DSi} / \mathrm{PO}_{4}-\mathrm{P}$ ratios in the inshore waters of the SWLZB were mainly associated with the distribution patterns of DIN and DSi concentrations.

In coastal waters, potential nutrient limitation could occur for $\mathrm{P}$ at $\mathrm{Si}: \mathrm{P}>22$ and $\mathrm{N}: \mathrm{P}>22$, for $\mathrm{N}$ at $\mathrm{N}: \mathrm{P}<10$ and $\mathrm{Si}: \mathrm{N}>1$, and for $\mathrm{Si}$ at $\mathrm{Si}: \mathrm{P}<10$ and $\mathrm{Si}: \mathrm{N}<1$ (Justić et al., 1995). Based on these criteria, the results of this study indicated that the inshore waters of the SWLZB, on the whole, were potentially P-limited, because the concentrations of dissolved nutrients in all the marine sampling sites showed a N:P ratio of higher than 22:1 and they in more than half of the marine sampling sties showed a Si:P ratio of higher than 22:1 (Fig. 6). Similar P limitation was also found in the inshore regions of the Changjiang Estuary (Chai et al., 2009), indicating that P limitation may be a common characteristic in river impacted coastal oceans of China. Nutrient acquisition is a major factor determining the outcome of competitive interactions and phytoplankton community composition (i.e., the species that make up the community). In P-limited ecosystems, ambient P concentrations governed phytoplankton growth rates and primary productivity (Goldman et al., 1979). 

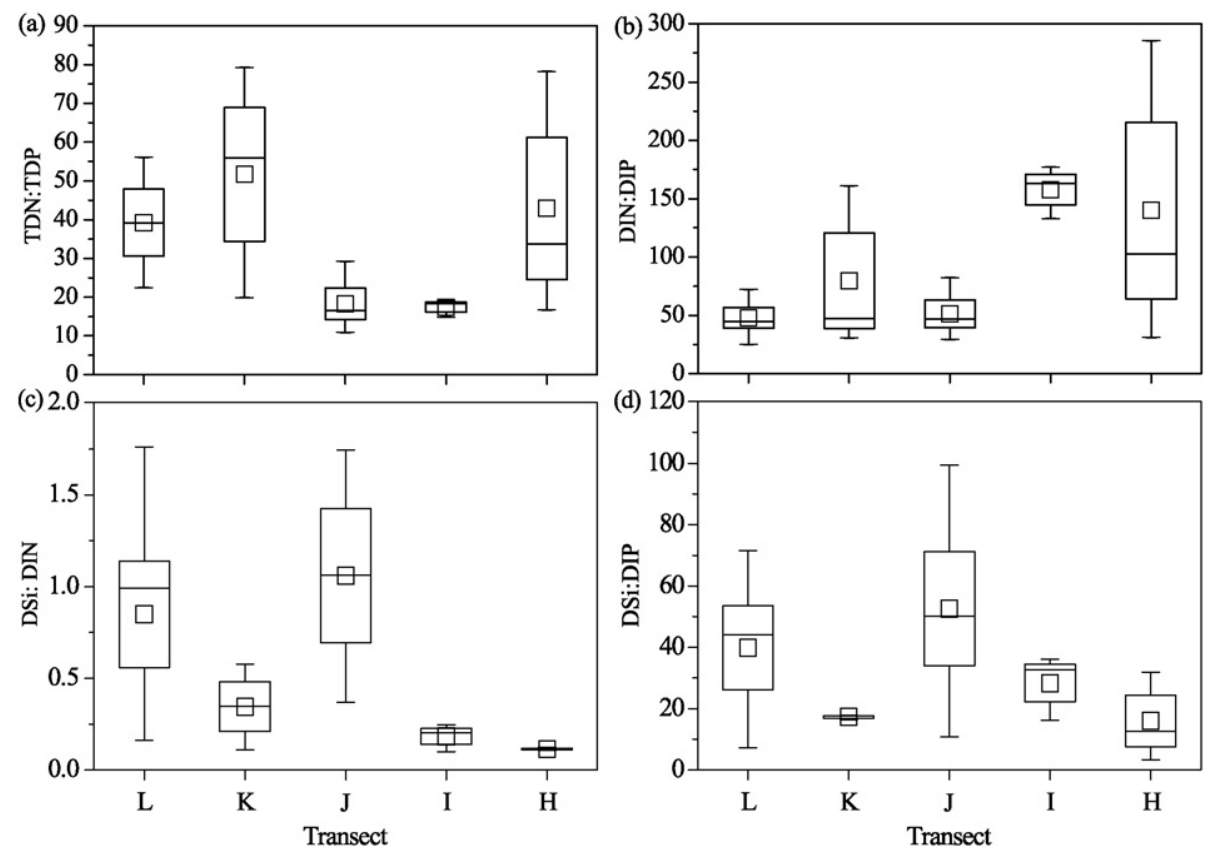

Fig. 5. Nutrient molar ratios in the inshore surface waters of the SWLZB.

\subsection{Relationship between nutrients and acidification in the SWLZB}

According to the above discussions, the N, P, Si concentration and structure in different sampling transects in the coastal waters of the SWLZB varied considerably (Fig. 4) depending on the specific contributors, and these variations were inevitably connected with the physicochemical characteristics of the sampling waters. Here, Origin software was used to analyze the correlation between $\mathrm{pH}_{\mathrm{T}}$ (as an acidification index) and the concentrations of TDN, DIN, DON, DSi, TDP, $\mathrm{PO}_{4}-\mathrm{P}$ and DOP, and the ratios of TDN/TDP, DIN/PO 4 -P, DSi/DIN and DSi/PO 4 -P. The results were shown in Figs. 7 and 8, which revealed that $\mathrm{pH}_{\mathrm{T}}$ was significantly negatively correlated with the concentrations of $\mathrm{NH}_{4}-\mathrm{N}$, $\mathrm{NO}_{3}-\mathrm{N}$, DIN and DSi, in the surface waters of the SWLZB, but not correlated well with $\mathrm{PO}_{4}-\mathrm{P}, \mathrm{DON}$ and DOP concentration, and TDN/TDP, DSi/ DIN and DIN/ $/ \mathrm{PO}_{4}-\mathrm{P}$ ratios, respectively. The general negative correlation between $\mathrm{pH}_{\mathrm{T}}$ and nutrient concentration suggested the enrichment of some certain nutrients could enhance acidification in the inshore waters of the SWLZB. $\mathrm{pH}_{\mathrm{T}}$ presented poor correlation with nutrient ratios, indicating that the changes in the structure of nutrients had limited influence on acidification.

\subsubsection{Nutrient distribution and acidification}

Correlations between $\mathrm{pH}_{\mathrm{T}}$ and the concentrations of $\mathrm{NH}_{4}-\mathrm{N}, \mathrm{NO}_{3}-\mathrm{N}$, $\mathrm{NO}_{2}-\mathrm{N}$, DIN, DON and TDN were shown in Fig. 7a-f, as what can be seen that $\mathrm{pH}_{\mathrm{T}}$ in the coastal waters of the SWLZB presented a significant

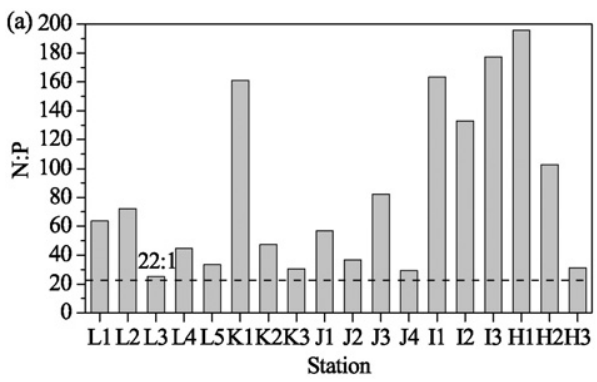

negative correlation with $\mathrm{NH}_{4}-\mathrm{N}(P<0.01, n=48), \mathrm{NO}_{3}-\mathrm{N}(P<0.05$, $n=48), \mathrm{NO}_{2}-\mathrm{N}(P<0.01, n=48)$, DIN $(P<0.001, n=48)$, DON $(P<0.05, n=48)$, and TDN $(P<0.01, n=48)$, respectively. All the data in the coastal SWLZB revealed that higher dissolved nitrogen concentrations were accompanied with lower $\mathrm{pH}_{\mathrm{T}}$. Furthermore, because nitrogen speciation can also affect the cell-size distribution of phytoplankton communities, the larger species may have the capacity for more internal storage of nutrients and become dominant in fluctuating nutrient regimes (Margalef, 1978; Turpin and Harrison, 1979), and in general, smaller species have a higher preference for $\mathrm{NH}_{4}-\mathrm{N}$ uptake over $\mathrm{NO}_{3}-\mathrm{N}$ than larger phytoplankton species (Stolte et al., 1994), so different regions which have different sources and concentrations of $\mathrm{N}$ compounds may have different species in making up the phytoplankton community. Carbon dioxide $\left(\mathrm{CO}_{2}\right)$ released into the seawater in the respiration process of phytoplankton can lower the $\mathrm{pH}_{\mathrm{T}}$ (that is, increasing acidity) of the subsurface waters, but different species of phytoplankton have different patterns and rates of respiration. The knock on effect was that the regions which have different sources and concentrations of $\mathrm{N}$ compounds may endure different degrees of acidification.

Correlations between $\mathrm{pH}_{\mathrm{T}}$ and $\mathrm{PO}_{4}-\mathrm{P}$, DOP and TDP were shown in Fig. $7 \mathrm{~g}-\mathrm{i}$. The data in the SWLZB revealed a negative effects of $\mathrm{PO}_{4}-\mathrm{P}$, DOP and TDP on $\mathrm{pH}_{\mathrm{T}}$, but all of them did not present close correlation with $\mathrm{pH}_{\mathrm{T}}(P>0.05, n=48)$. Correlation between $\mathrm{pH}_{\mathrm{T}}$ and DSi was shown in Fig. 7j. A significant negative correlation could be found between $\mathrm{pH}_{\mathrm{T}}$ and DSi concentrations $(P<0.001, n=48)$. The total nutrient concentrations ( $\mathrm{T}$ nutrients $=\mathrm{TDN}+\mathrm{TDP}+\mathrm{DSi}$ ) also showed a

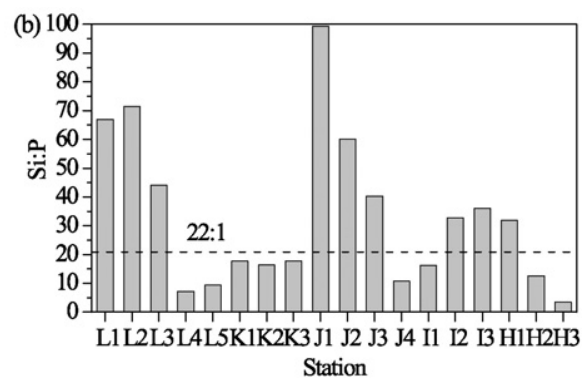

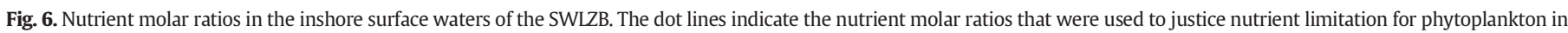
coastal waters in Justić et al. (1995). 

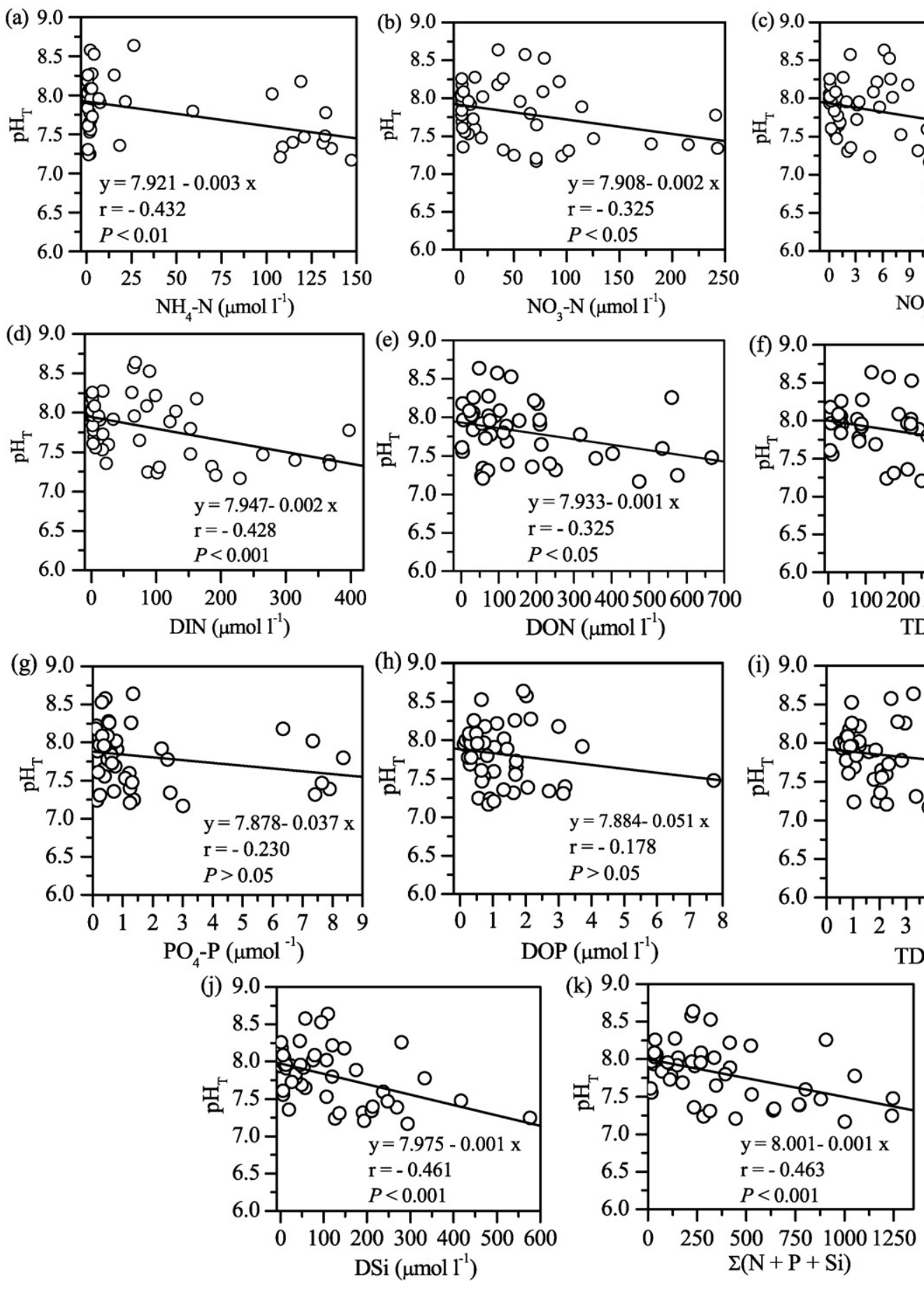
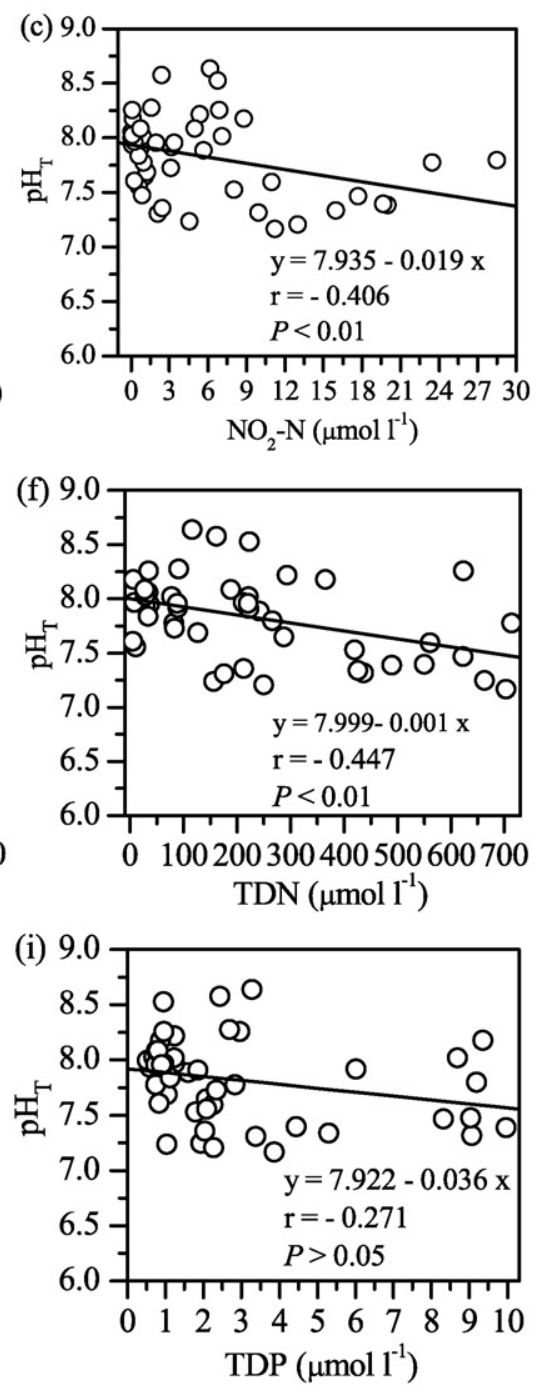

Fig. 7. Correlation between $\mathrm{pH}_{\mathrm{T}}$ and nutrient concentrations.

significant negative correlation with $\mathrm{pH}_{\mathrm{T}}(P<0.001, n=48)$ in the studied areas (Fig. 7k). Combining the above-mentioned data and discussions, it could be concluded that the enrichment of inorganic $\mathrm{N}$ and $\mathrm{Si}$ may enhance acidification in the SWLZB. Acidification is often accompanied with lower dissolved oxygen concentration, a common phenomenon of acidified regions related to eutrophication caused by nutrient enrichment (Chen et al., 2007; Gilbert et al., 2010), which in turn facilitates sediment nutrient release. Sediment nutrient release may further stimulate algal blooms, leading to a positive feedback loop that perpetuates blooms and eutrophication, subsequently to acidification.

However, the linkage between nutrient loading, eutrophication and hypoxia/anoxia dynamics is often non-linear and complex in estuarine and coastal systems (Cloern, 2001), so is to acidification. This is because these systems are hydrodynamically and biogeochemically distinct and highly variable. Climatic and physiographic differences between these systems affect profoundly physical-chemical and biological processes mediating organic matter production and accumulation, oxygen dynamics, nutrient cycling and acidity.

\subsubsection{Nutrient structure and acidification}

Previous research has shown that phytoplankton species exhibit different growth responses to $\mathrm{N}$ sources (Collos, 1989). In particular, $\mathrm{NO}_{3}-\mathrm{N}$ and $\mathrm{NH}_{4}$-N uptake rates vary spatially and seasonally, suggesting differential community responses to the $\mathrm{N}$ sources (Boyer et al., 1994). These species-specific responses may play an important role in structuring natural phytoplankton communities (Stolte et al., 1994). Thus 

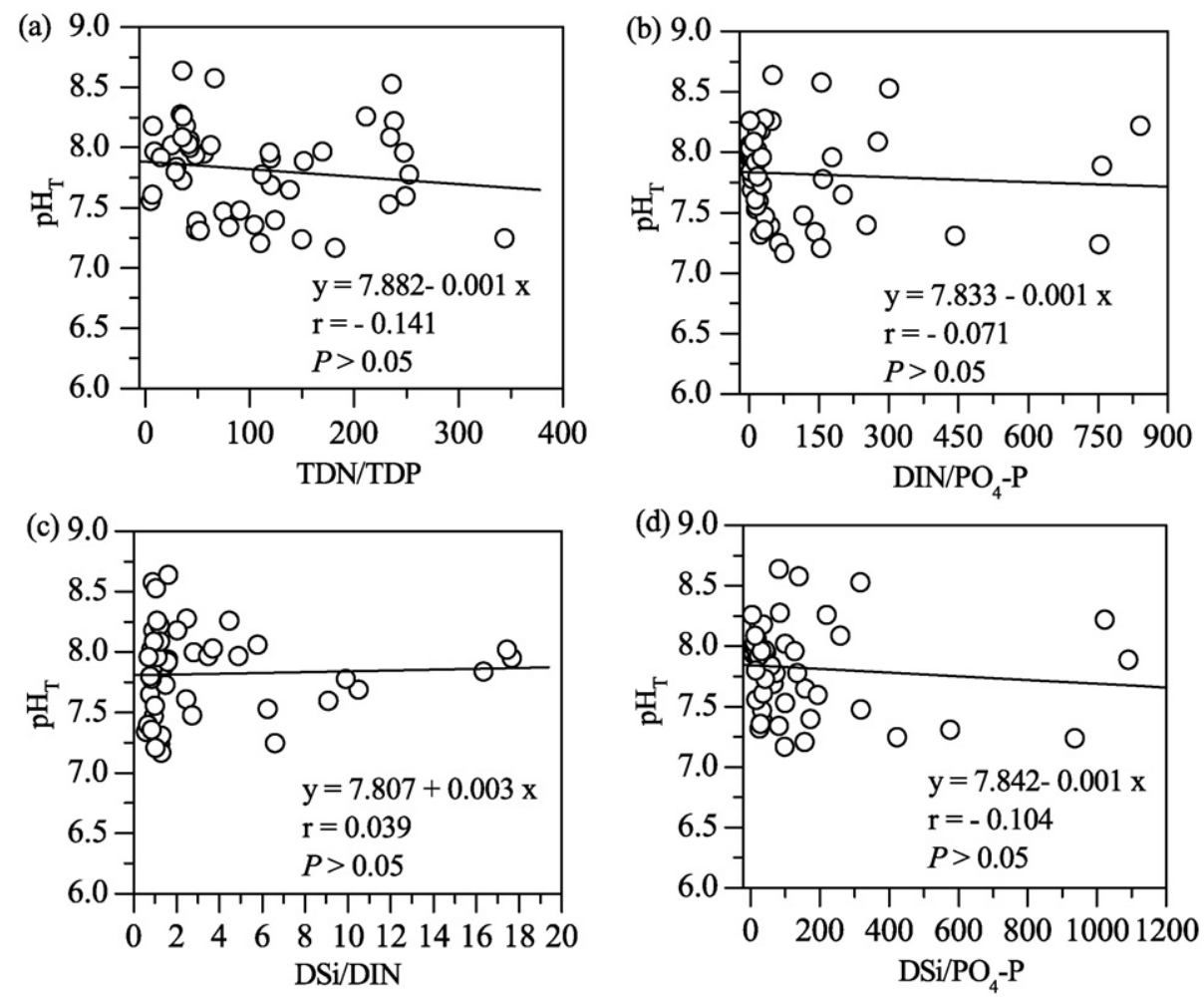

Fig. 8. Correlation between $\mathrm{pH}_{\mathrm{T}}$ and nutrient molar ratios.

alteration of nutrient ratios may also change the phytoplankton community composition significantly, with subsequently knock on effect of alteration of acidification degree. Correlations between $\mathrm{pH}_{\mathrm{T}}$ and TDN/TDP, DIN/PO $4-\mathrm{P}, \mathrm{DSi} / \mathrm{DIN}$ and $\mathrm{DSi} / \mathrm{PO}_{4}-\mathrm{P}$ ratios were shown in Fig. 8. In the present study, TDN/TDP, DSi/DIN, DSi/PO $-\mathrm{P}$ and DIN/PO $/$-P ratios did not present close correlation with $\mathrm{pH}_{\mathrm{T}}$, respectively, suggesting that phytoplankton respiration was probably not the major reason for acidification in the SWLZB, and changing the nutrient ratios has limited effects on acidification in the SWLZB.

\subsubsection{Mechanisms of nutrient affecting acidification}

$\mathrm{OA}$ is directly related to $\mathrm{CO}_{2}$ in the seawater; all the factors which can change the $\mathrm{CO}_{2}$ concentration in the seawater could affect $\mathrm{OA}$. Nutrient enrichment could enhance primary productivity which produces more organic matter (OM) in the seawater (Diaz and Rosenberg, 2008; Doney, 2010; Gilbert et al., 2010). The increase in primary production associated with nutrient enrichment will increase the concentrations of OM by two main mechanisms: secretion of mucopolysaccharides by phytoplankton, especially under conditions of stress, and bacterial degradation of phytoplankton-derived DOM and subsequent release of DOM and nutrients (Azam et al., 1983, 1993; Kirchman, 1991). DOM (e.g., glucose, urea, amino acids) may contain many inorganic nutrients required for the growth and metabolism of heterotrophic bacteria in aquatic systems (Azam et al., 1983, 1993; Kirchman et al., 1991). CO 2 released into the seawater in the respiration process of OM can lower the $\mathrm{pH}$ (that is, increasing acidity) of the subsurface waters in the same region. OM respiration can be illustrated as follows (Cai et al., 2011):

$\mathrm{OM}+\mathrm{O}_{2} \rightarrow \mathrm{CO}_{2}+\mathrm{HNO}_{3}$

$\mathrm{NH}_{4}+\mathrm{O}_{2}+\mathrm{HNO}_{3}+\mathrm{OM} \rightarrow \mathrm{CO}_{2}+\mathrm{N}_{2}$

As can be seen in such a process not only $\mathrm{CO}_{2}$ is produced but also $\mathrm{O}_{2}$ consumed. So nutrient enrichment related eutrophication often causes low $\mathrm{O}_{2}$ concentration. Biomass decomposition is often an $\mathrm{O}_{2}$-demanding process (Wallace et al., 2014). Therefore, waters enriched with readily degraded or "reactive" organic matter tend to consume large amounts of $\mathrm{O}_{2}$. If the affected waters are vertically stratified, slowly flushed, and/or stagnant, consumption of $\mathrm{O}_{2}$ may exceed its re-supply from either atmospheric or in-stream photosynthetic (i.e., $\mathrm{O}_{2}$ evolution) sources. The imbalance between relatively high rates of $\mathrm{O}_{2}$ consumption and low rates of $\mathrm{O}_{2}$ re-supply causes DO concentration to drop to levels that are low enough to adversely affect oxygen-requiring animal and plant life (Diaz and Rosenberg, 1995; Wallace et al., 2014).

Respiration of OM below the pycnocline introduces additional $\mathrm{CO}_{2}$ into the subsurface waters, hence reducing the $\mathrm{pH}$ and seawater carbonate saturation state. When $\mathrm{O}_{2}$ is available, the most important respiration process is as follows (Cai et al., 2011):

$$
\begin{aligned}
& \left(\mathrm{CH}_{2} \mathrm{O}\right)_{106}\left(\mathrm{NH}_{3}\right)_{16} \mathrm{H}_{3} \mathrm{PO}_{4}+138 \mathrm{O}_{2} \rightarrow 106 \mathrm{CO}_{2} \uparrow+16 \mathrm{HNO}_{3}+\mathrm{H}_{3} \mathrm{PO}_{4} \\
& \quad+122 \mathrm{H}_{2} \mathrm{O}
\end{aligned}
$$

Note that on hydration $\mathrm{CO}_{2}$ becomes carbonic acid and the production of a small amount of the strong acid, $\mathrm{HNO}_{3}$, may play a role to some extent in reducing $\mathrm{pH}$ and total alkalinity (TA) (Canfield et al., 1993; Lohrenz et al., 2010).

In the aquatic system, $\mathrm{NO}_{3}-\mathrm{N}$ and $\mathrm{NH}_{4}-\mathrm{N}$ may perform as weak acid and base, respectively, and different phytoplankton communities consume different amounts of $\mathrm{NO}_{3}-\mathrm{N}$ and $\mathrm{NH}_{4}-\mathrm{N}$ (Stolte et al., 1994), resulting in $\mathrm{NO}_{3}-\mathrm{N}$ presenting negative correlation with $\mathrm{pH}_{\mathrm{T}}$ (Fig. $7 \mathrm{~d}$, enhance acidification) and $\mathrm{NH}_{4}-\mathrm{N}$ presenting negative correlation with $\mathrm{pH}_{\mathrm{T}}$ (Fig. 7f, mitigate acidification). Some composition of silicate minerals in water system may act as weak acid (e.g. $\mathrm{Na}_{2} \mathrm{SiO}_{3}, \mathrm{~K}_{2} \mathrm{SiO}_{3}$, $\mathrm{KNaSiO}_{3}$, etc.); furthermore, DSi supports the major phytoplankton community-diatom in coastal water system, (Stolte et al., 1994; Diaz and Rosenberg, 2008; Doney, 2010; Gilbert et al., 2010), which release $\mathrm{CO}_{2}$ into seawater during respiration. Therefore, higher DSi concentration was accompanied with lower $\mathrm{pH}_{\mathrm{T}}$ value in this research (Fig. $7 \mathrm{j}, \mathrm{c}$, $\mathrm{d}$, enhance acidification).

Since $\mathrm{P}$ was the potential nutrient limitation of phytoplankton growth in the SWLZB, primary productivity in this region may be sensitive to $\mathrm{PO}_{4}-\mathrm{P}$ concentrations, and higher $\mathrm{PO}_{4}-\mathrm{P}$ concentrations could 
induce higher $\mathrm{OM}$ concentrations, consequently inducing lower $\mathrm{pH}$ values. However, the $\mathrm{pH}_{\mathrm{T}}$ presented poor correlation with $\mathrm{PO}_{4}-\mathrm{P}$ concentrations (Fig. $7 \mathrm{~g}$ ), suggesting that the input of acid materials (e.g. $\mathrm{NO}_{3}-\mathrm{N}, \mathrm{Na}_{2} \mathrm{SiO}_{3}, \mathrm{~K}_{2} \mathrm{SiO}_{3}$, etc.) rather than OM respiration may be the major reasons for acidification in the SWLZB.

\section{Conclusion}

In this research, the $\mathrm{pH}_{\mathrm{T}}$ values in the inshore waters of the SWLZB were found to vary from 7.56 to 8.26 with an average of 7.93 , which was significantly below the mean $\mathrm{pH}_{\mathrm{T}}$ value of the world oceans, and the decadal change of $\mathrm{pH}$ values in the bay demonstrates a decreasing trend, indicating a sign of acidification, suggesting that the SWLZB are experiencing acidification.

The dissolved nitrogen in the SWLZB varied greatly along the coast corresponding to different contributors. It decreased significantly in the seaward direction. The SWLZB was enriched with nitrogen. The distribution pattern of nutrients in the marine sampling transects is generally similar to that of nutrients in their corresponding rivers which indicated that the transportation and behavior of nutrients in the SWLZB were heavily influenced by river inputs and anthropogenic activities. The general DIN structure in the L-transect and the K-transect was $\mathrm{NH}_{4}-\mathrm{N}>\mathrm{NO}_{3}-\mathrm{N}>\mathrm{NO}_{2}-\mathrm{N}$; in the J-transect, the I-transect and the $\mathrm{H}$-transect, it was $\mathrm{NO}_{3}-\mathrm{N}>\mathrm{NH}_{4}-\mathrm{N}>\mathrm{NO}_{2}-\mathrm{N}$; the average concentrations of $\mathrm{NO}_{2}-\mathrm{N}$ in the five sampling transects remained at the same level, indicating that $\mathrm{NO}_{2}-\mathrm{N}$ in the studied region was very likely to be from non-point sources.

The concentration of dissolved phosphorus decreased from the estuaries to the sea; the average concentrations of reactive phosphorus in the five marine sampling transects were relatively low. The inshore waters of the SWLZB had high nitrogen concentrations and low phosphorus concentrations. There were $>70 \%$ of the sampling sites exhibiting a condition of potential P limitation in the inshore waters of the SWLZB.

In the SWLZB, $\mathrm{pH}_{\mathrm{T}}$ was significantly negatively correlated with the concentration of DIN, $\mathrm{NO}_{3}-\mathrm{N}$, DSi and total nutrient, respectively. The negative correlation between $\mathrm{pH}_{\mathrm{T}}$ and nutrients suggested the enrichment of some certain nutrients enhanced acidification in the SWLZB In the P limitation circumstances more inorganic $P$ would be beneficial for some kinds of biomass, and more $\mathrm{CO}_{2}$ will be released into seawater. But $\mathrm{pH}_{\mathrm{T}}$ in the $\mathrm{SWLZB}$ presented poor correlation with $\mathrm{PO}_{4}$-P concentration and nutrient ratios, suggesting that the input of acid materials (e.g. $\mathrm{NO}_{3}-\mathrm{N}, \mathrm{Na}_{2} \mathrm{SiO}_{3}, \mathrm{~K}_{2} \mathrm{SiO}_{3}$, etc.) rather than $\mathrm{OM}$ respiration may be the major reasons for acidification in the inshore waters of the SWLZB.

\section{Acknowledgements}

The authors are grateful to all the group members for their constant field and laboratory assistance, helpful advice and in-depth discussion. This study was co-supported by the Strategic Priority Research Program of the Chinese Academy of Sciences (XDA11020305, XDA11020102, XDA11020702) and the National Natural Science Foundation of China (41376083).

\section{References}

Alongi, D.M., 1998. Coastal Ecosystem Processes. CRC Press, pp. 419-425.

Azam, F., Fenchel, T., Field, G.J., Gray, J.S., Meyer-Reil, L.A., Thingstad, F., 1983. The ecological role of water-column microbes in the sea. Mar. Ecol. Prog. Ser. 10, 257-263.

Azam, F., Smith, D.C., Steward, G.F., Hagstrom, A., 1993. Bacteria-organic matter coupling and its significance for oceanic carbon cycling. Microb. Ecol. 28, 167-179.

Boyer, J.N., Stanley, D.W., Christian, R.R., 1994. Dynamics of $\mathrm{NH}_{4}^{+}$and $\mathrm{NO}_{3}^{-}$uptake in the water column of the Neuse River Estuary, North Carolina, USA. Estuaries 17, 361-371.

Cai, W.J., Hu, X.P., Huang, W.J., Murrell, M.C., Lehrter, J.C., Lohrenz, S.E., Gong, G.C., 2011 Acidification of subsurface coastal waters enhanced by eutrophication. Nat. Geosci. $4,766-770$.

Caldeira, K., Wickett, M.E., 2003. Oceanography: anthropogenic carbon and ocean pH. Nature 425,365

Canadell, J.G., Le Quéré, C., Raupach, M.R., Field, C.B., Buitenhuis, E.T., Ciais, P., Marland, G 2007. Contributions to accelerating atmospheric $\mathrm{CO}_{2}$ growth from economic activity, carbon intensity, and efficiency of natural sinks. Proc. Natl. Acad. Sci. 104, $18866-18870$.

Canfield, D.E., Jørgensen, B.B., Fossing, H., Glud, R., Gundersen, J., Ramsing, N.B., Hall, P.O., 1993. Pathways of organic carbon oxidation in three continental margin sediments. Mar. Geol. 113, 27-40.

Chai, C., Yu, Z.M., Shen, Z.L., 2009. Nutrient characteristics in the Yangtze River Estuary and the adjacent East China Sea before and after impoundment of the Three Gorges Dam. Sci. Total Environ. 407, 4687-4695.

Chen, C.C., Gong, G.C., Shiah, F.K., 2007. Hypoxia in the East China Sea: one of the largest coastal low-oxygen areas in the world. Mar. Environ. Res. 64, 399-408.

Cheng, J.S., 2004. The Ecological Environment and Biological Community in Inshore Waters of Huanghai Sea and Bohai Sea. 5. China Ocean University Press, Oingdao, pp. 38-41 (In Chinese).

Cloern, J.E., 2001. Our evolving conceptual model of the coastal eutrophication problem. Mar. Ecol. Prog. Ser. 210, 223-253.

Collos, Y., 1989. A linear model of external interactions during uptake of different forms of inorganic nitrogen by microalgae. J. Plankton Res. 11, 521-533.

Cooley, S.R., Kite-Powell, H.L., Doney, S.C., 2009. Ocean acidification's potential to alter global marine ecosystem services. Oceanography 22, 172-181.

Diaz, R.J., Rosenberg, R., 1995. Marine benthic hypoxia: a review of its ecological effects and the behavioural responses of benthic macrofauna. Oceanogr. Mar. Biol. Annu. Rev. 33, 245-303.

Diaz, R.J., Rosenberg, R., 2008. Spreading dead zones and consequences for marine ecosystems. Science 321, 926-929.

Doney, S.C., 2010. The growing human footprint on coastal and open-ocean biogeochemistry. Science 328, 1512-1516.

Dongying Statistical Yearbook, 2013. Dongying City Bureau of Statistics, National Bureau of Statistics in Dongying Survey Team, 2013. China Statistics Press, Beijing (In Chinese).

Dürr, H.H., Laruelle, G.G., van Kempen, C.M., Slomp, C.P., Meybeck, M., Middelkoop, H., 2011. Worldwide typology of near shore coastal systems: defining the estuarine filter of river inputs to the oceans. Estuar. Coasts 34, 441-458.

Gao, X.L., Song, J.M., 2005. Phytoplankton distributions and their relationship with the environment in the Changjiang Estuary, China. Mar. Pollut. Bull. 50, 327-335.

Gattuso, J.P., Hansson, L., 2011. Ocean Acidification: Background and History. Ocean Acidification. Oxford University Press, Oxford, pp. 1-20.

Gattuso, J.P., Frankignoulle, M., Wollast, R., 1998. Carbon and carbonate metabolism in coastal aquatic ecosystems. Annu. Rev. Ecol. Syst. 29, 405-434.

Gilbert, D., Rabalais, N.N., Diaz, R.J., Zhang, J., 2010. Evidence for greater oxygen decline rates in the coastal ocean than in the open ocean. Biogeosciences 7, 2283-2296.

Goldman, J., McCarthy, J., Peavy, D., 1979. Growth rate influence on the chemical composition of phytoplankton in oceanic waters. Nature 279, 210-215.

Halpern, B.S., Walbridge, S., Selkoe, K.A., Kappel, C.V., Micheli, F., D'Agrosa, C., Watson, R., 2008. A global map of human impact on marine ecosystems. Science 319, 948-952.

Jiang, T.L., Xu, H.D., Pan, H.Z., Ying, X.C., 1991. Present situation and evaluation of the water environments in the southwest of Laizhou Bay. Mar. Sci. Bull. 2, 17-52 (In Chinese).

Justić, D., Rabalais, N.N., Turner, R.E., Dortch, Q., 1995. Changes in nutrient structure of river-dominated coastal waters: stoichiometric nutrient balance and its consequences. Estuar. Coast. Shelf Sci. 40, 339-356.

Kiedrzyńska, E., Jóźwik, A., Kiedrzyński, M., Zalewski, M., 2014. Hierarchy of factors exerting an impact on the nutrient load of the Baltic Sea and sustainable management of its drainage basin. Mar. Pollut. Bull. 88, 162-173.

Kirchman, D.L., Suzuki, Y., Garside, C., Ducklow, H.W., 1991. High turnover rates of dissolved organic carbon during a spring phytoplankton bloom. Nature 352, 612-614.

Liu, S.M., Li, R.H., Zhang, G.L., Wang, D.R., Du, J.Z., Herbeck, L.S., Ren, J.L., 2011. The impact of anthropogenic activities on nutrient dynamics in the tropical Wenchanghe and Wenjiaohe Estuary and Lagoon system in East Hainan, China. Mar. Chem. 125, 49-68.

Liu, S.M., Li, L.W., Zhang, G.L., Liu, Z., Yu, Z.G., Ren, J.L, 2012. Impacts of human activities on nutrient transports in the Huanghe (Yellow River) estuary. J. Hydrol. 430-431, 103-110.

Lohrenz, S.E., Cai, W.J., Chen, F., Chen, X., Tuel, M., 2010. Seasonal variability in air-sea fluxes of $\mathrm{CO}_{2}$ in a river-influenced coastal margin. J. Geophys. Res. 115, C10034.

Ma, S.S., Xin, F.Y., Cui, Y., Qiao, X.Y., 2004. Assessment of main pollution matter volume into the sea from Yellow River and Xiaoqing River. Mar. Fish. Res. 25 (5), 47-51 (In Chinese with English abstract).

Margalef, R., 1978. Life-forms of phytoplankton as survival alternatives in an unstable environment. Oceanol. Acta 1, 493-509.

Mi, T.Z., Yu, Z.G., Yao, Q.Z., Zhang, J., 2001. Dissolved nutrient in the south of Laizhou Bay in spring. Mar. Environ. Sci. 20 (3), 14-18 (In Chinese)

Qin, X.L., 2010. Study of Low-Carbon Economy Development Model in Weifang Binhai Development Area. Shandong University, pp. 14-18 (Master's Thesis).

Qu, H.J., Kroeze, C., 2010. Past and future trends in nutrients export by rivers to the coastal waters of China. Sci. Total Environ. 408, 2075-2086.

Quéré, C.L., Andres, R.J., Boden, T., Conway, T., Houghton, R.A., House, J.I., Zeng, N., 2013. The global carbon budget 1959-2011. Earth Syst. Sci. Data 5, 165-185.

Ryuichi, S., Ryuji, A., Kuo, F.H., Chen, F.Y., Yasufumi, I., 2013. Ocean acidification trend in the tropical North Pacific since the mid-20th century reconstructed from a coral archive. Mar. Geol. 342, 58-64.

Seitzinger, S.P., Harrison, J.A., Dumont, E., Beusen, A.H., Bouwman, A.F., 2005. Sources and delivery of carbon, nitrogen, and phosphorus to the coastal zone: An overview of Global Nutrient Export from Watersheds (NEWS) models and their application. Glob. Biogeochem. Cycles 19, GB4S01. http://dx.doi.org/10.1029/2005GB002606.

Smetacek, V., Zingone, A., 2013. Green and golden seaweed tides on the rise. Nature 504, $84-88$.

SOA (State Oceanic Adiministration of China), 2004. China Marine Statistical Yearbook 2003. China Ocean Press, Beijing (In Chinese). 
SOA (State Oceanic Adiministration of China), 2005. China Marine Statistical Yearbook 2004. China Ocean Press, Beijing (In Chinese).

SOA (State Oceanic Adiministration of China), 2010. China Marine Statistical Yearbook 2009. China Ocean Press, Beijing (In Chinese).

SOA (State Oceanic Administration of China), 2009. Marine Environment Quality Bulletin of China, 2008. (<http://www.coi.gov.cn/gongbao/nrhuanjing/nr2008/ 201107/ t20110729_18793.html>. (In Chinese)).

SOA (State Oceanic Administration of China), 2012. Marine Environment Quality Bulletin of China, 2011. (<http://www.coi.gov.cn/gongbao/nrhuanjing/nr2011/ 201207/ t20120710_23199.html>. (In Chinese)).

Song, J.M., 2011. Biogeochemical Processes of Biogenic Elements in China Marginal Seas. Springer Science \& Business Media and Zhejiang University Press.

Stolte, W., McCollin, T., Noordeloos, A., Riegman, R., 1994. Effect of nitrogen source on the size distribution within marine phytoplankton populations. J. Exp. Mar. Biol. Ecol. 184, 83-97.

Turpin, D.H., Harrison, P.J., 1979. Limiting nutrient patchiness and its role in phytoplankton ecology. J. Exp. Mar. Biol. Ecol. 39, 151-166.
Wallace, R.B., Baumann, H., Grear, J.S., Aller, R.C., Gobler, C.J., 2014. Coastal ocean acidification: the other eutrophication problem. Estuar. Coast. Shelf Sci. 148, 1-13.

Xing, Q.G., Luigi, T., Braga, F., Gao, X.L., Gao, M., 2015. Interpreting the progressive eutrophication behind the world's largest macroalgal blooms with water quality and ocean color data. Nat. Hazards http://dx.doi.org/10.1007/s11069-015-1694-X.

Ying, W.H., Cui, W.L., Song, W.P., Zhang, Y.B., 2014. The Bohai Sea Chemical Environment Investigation and Research. China Ocean Press, Beijing (In Chinese).

Zhai, W.D., Zhao, H.D., Zheng, N., Xu, Y., 2012. Coastal acidification in summer bottom oxygen-depleted waters in northwestern-northern Bohai Sea from June to August in 2011. Chin. Sci. Bull. 57, 1062-1068.

Zhang, J.F., Gao, X.L., Li, P.M., Zhuang, W., Zhou, F.X., 2015. Nutrient distribution characteristics and long-term trends in the southwest of the Laizhou Bay and its adjacent rivers. Mar. Sci. Bull. 2, 222-232 (In Chinese). 